\title{
Control of weeds in glasshouse and rice field conditions by phytotoxic effects of Tinospora crispa (L.) Hook. f. \& Thomson leaves
}

Farzad Aslani ${ }^{1 *}$, Abdul S. Juraimi ${ }^{1}$, Muhammad S. Ahmad-Hamdani ${ }^{1}$, Farahnaz S.G. Hashemi², and Md. Amirul Alam ${ }^{3}$

\section{ABSTRACT}

Phytotoxic potential of powder and methanol extract of Tinospora crispa (L.) Hook. f. \& Thomson leaves as pre- and post-emergence applications on the growth of transplanted rice (Oryza sativa L.) and associated weeds were evaluated under glasshouse and field conditions to determine its herbicidal activity as soil additive material in rice fields. In glasshouse study, utilization of leaf powder and leaf extract of $T$. crispa as pre-emergence application provided a satisfactory weed control, inhibiting seed germination and reducing the growth of germinated seedlings with an increase in the yield of transplanted rice. The magnitude of the phytotoxic effects at the same concentration levels in the test plants was dependent on the application methods (powder and extract), time of application (pre-and post-emergence), concentration and the recipient species. Field experiment consisted of $T$. crispa leaf powder $\left(1,2\right.$ and $\left.4 \mathrm{tha}^{-1}\right)$, chemical herbicide (pretilachlor + pyribenzoxim at $1 \mathrm{~L} \mathrm{ha}^{-1}$ ) as positive control and a negative control (no treatment). There was nonsignificant difference between leaf powder-treated plots ( 2 and $4 \mathrm{t} \mathrm{ha}^{-1}$ doses) and plots that received herbicidal treatment in terms of percentage reduction of emergence and weed DM. In plots amended with 1,2 and $4 \mathrm{t} \mathrm{ha}^{-1}$ leaf powder, weed dry weight was reduced by nearly $80 \%, 97 \%$ and $99 \%$ and total weed seedling density was inhibited by $73 \%, 94 \%$ and $99 \%$, respectively, compared to untreated plots. There was a significant promotion on grain yield, straw dry weight and number of seed per panicle of rice, when treated with leaf powders and chemical herbicide compared with negative control. These results suggest that $T$. crispa has a significant phytotoxic activity on the germination and growth of weed species in rice fields.

Key words: Leaf powder, leaf extract, Oryza sativa, phytotoxicity, post-emergence application, pre-emergence application.

${ }^{1}$ Universiti Putra Malaysia (UPM), Faculty of Agriculture, 43400 Serdang, Selangor, Malaysia.

"Corresponding author (aslani.farzad.1362@gmail.com).

${ }^{2}$ Institute of Tropical Agriculture, Universiti Putra Malaysia (UPM), 43400 Serdang, Selangor, Malaysia.

${ }^{3}$ Universiti Sultan Zainal Abidin, Faculty of Bioresources and Food Industry, 21300, Terengganu, Malaysia.

Received: 31 May 2016.

Accepted: 9 October 2016.

doi:10.4067/S0718-58392016000400006

\section{INTRODUCTION}

Rice (Oryza sativa L.) is life for most people living in Asia (Gnanamanickam, 2009). In Malaysia, the total consumption of rice has increased from 2.7 million tons in 1985 to 4 million tons in 2009 because of the increasing population (Alias et al., 2011). Weed infestations are recognized as a serious biological constraint to rice production in both lowland and upland ecosystems (Saito, 2010).

The repeated use and strong reliance on herbicides has led to the development of resistance in weed species. It has also negative effects on both the environment and human health (Beltran et al., 2012). In this relation, scientists have made tremendous efforts to reduce the reliance on chemical weed managements through developing effective natural herbicides (Kato-Noguchi et al., 2013). Allelopathy exploitation is one of the alternative methods. Allelopathy as a tool can be used to combat the challenges of environmental pollution and herbicide resistance development (Jabran et al., 2015).

The extraction of the plant tissues is the isolation of bioactive compounds (Mijangos Ricárdez et al., 2011). Extracts can be used as a medium for expression of allelochemical activity to suppress weed growth (Macías et al., 2007). Several researchers have shown the use of plant extracts for weed suppression as pre-emergence and foliar spray in the laboratory and application under glasshouse and field conditions (Haq et al., 2010; Omezzine et al., 2011; Dadkhah, 2013).

Many studies have been conducted using dry material of allelopathic plants for managing rice weeds under natural conditions. Dry material of four medicinal plants (Passiflora incarnata L., Nerium oleander L., Helianthus tuberosus L., and Alocasia cucullata [Lour.] G. Don) significantly suppressed growth of rice weeds in a greenhouse at various doses (Khanh et al., 2005).

Tinospora crispa (L.) Hook. f. \& Thomson, Malay name Batawali, belongs to the family Menispermaceae, is a traditional medicinal plant (Forman, 1981), a wild plant that grows in primary rainforests in all parts of Malaysia, Thailand and Indonesia. Pukclai and Kato-Noguchi (2010) screened eleven Thai medicinal plants in terms of their allelopathic activity. They found $T$. tuberculata as a most phytotoxic plant on the seedling growth of five tested plants. They isolated two growth inhibitory compounds (Ti-1 and Ti-2), which may play important roles in the allelopathic activity of T. tuberculata (Pukclai and KatoNoguchi, 2012). In another study, syringin has been identified as an allelochemical from the methanol extract of T. tuberculata (Kato-Noguchi et al., 2014a). In the preliminary studies, $T$. 
tuberculata leaves were found to be more toxic than the stems to the suppression of target plant species. Tinospora tuberculata leaves are rich in number and concentration of inhibitory components that are responsible for herbicidal activity of leaves (Aslani et al., 2013; 2014; 2015).

We speculated that $T$. crispa has potent phytotoxic potential to contribute towards weed management in rice cultivation systems. Therefore, a combination of the glasshouse and field experiments were performed to determine the phytotoxic effects of powder and methanol extract of $T$. crispa leaves on rice yield, and germination and growth of associated weeds with a view of its possible utilization as a natural herbicide in rice fields.

\section{MATERIALS AND METHODS}

\section{Test materials}

Tinospora crispa plants growing in the Herbal Garden of University Putra Malaysia, Selangor, Malaysia, were used; leaves were cleaned several times with tap water and airdried for $3 \mathrm{wk}$, then ground to a fine powder in a laboratory blender and sieved through a 40-mesh sieve. The leaf powder was stored at $4{ }^{\circ} \mathrm{C}$ until use.

Commercial seeds of barnyard grass (Echinochloa crus-galli [L.] P. Beauv.), small-flower umbrella sedge (Cyperus difformis L.) and weedy rice (Oryza sativa L.) were purchased from Herbiseed Company (London, UK). Barnyard grass seed coats were loosed by hand, one by one to improve germination percentage. The seeds of rice 'MR 219' were manually collected at the rice field, Universiti Putra Malaysia. Rice and weedy rice seeds were surface sterilized in a 1:10 (v/v) dilution of commercial hypochlorite bleach for $10 \mathrm{~min}$ and rinsed several times with distilled water. The seeds were cleaned, air-dried and all seeds stored in darkened, airtight containers at $-18{ }^{\circ} \mathrm{C}$ prior to their use. The germination of seeds was randomly checked and was $\sim 86 \%-95 \%$.

The soil used in the glasshouse experiments was collected from Tanjung Karang rice growing area, Selangor $\left(3^{\circ} 25^{\prime} \mathrm{N}, 101^{\circ} 1^{\prime} \mathrm{E}\right)$, Malaysia, at $10 \mathrm{~cm}$ depth. The soil was pulverized, and inert materials, visible insect pests and plant debris were removed. The soil was then crushed, mixed thoroughly, and sun dried. Some physicochemical characteristics of the soils were as follows: sand $23.1 \%$, silt $45.3 \%$, clay $31.6 \%, \mathrm{pH} 6.1$, electrical conductivity $1.36 \mathrm{EC}$ $\mathrm{dS} \mathrm{m}{ }^{-1}$, organic C $1.06 \%$, total $\mathrm{N} 0.13 \%$, and available $\mathrm{P}$ $13.12 \mathrm{mg} \mathrm{kg}^{-1}$.

\section{Extraction procedure}

Leaves of $T$. crispa (600 g) were soaked in methanol:distilled water $(80: 20, \mathrm{v} / \mathrm{v})(6 \mathrm{~L})$ to obtain methanol extract. They were shaken in an orbital shaker at room temperature $\left(24-26^{\circ} \mathrm{C}\right)$ for $48 \mathrm{~h}$. The solution was filtered through four layers of cheese cloth to remove debris and then centrifuged at $3000 \mathrm{rpm}$ for $1 \mathrm{~h}$. The supernatant was filtered through one layer of Whatman nr 42 filter paper. To prevent microorganism growth, the solution was filtered again through a $0.2 \mu \mathrm{m}$ Nalgene filter (Becton Dickinson Labware, Lincoln Park, New Jersey, USA). The methanol extracts were evaporated to dryness under vacuum at $40{ }^{\circ} \mathrm{C}$ using a rotary evaporator. In order to compare effectiveness of leaf powder and leaf extract, we used the same amount of leaf material to prepare varied doses of leaf powder and leaf extract. Thus, stock extract of $T$. crispa leaves was diluted appropriately with sterile distilled water to obtain extract concentration of $100 \% \mathrm{w} / \mathrm{v}$ for glasshouse experiments. Because, in this concentration, 1, 2, and $4 \mathrm{t} \mathrm{ha}^{-1} T$. tuberculata leaves were used to prepare 1000, 2000, and $4000 \mathrm{~L} \mathrm{ha}^{-1}$ leaf extract, respectively.

\section{Pre-emergence application of powder and methanol extract of $T$. crispa leaves on selected rice weeds}

The experiment was conducted at a glasshouse in Faculty of Agriculture, Universiti Putra Malaysia ( $3^{\circ} 02^{\prime} \mathrm{N}$, $101^{\circ} 42^{\prime}$ E, $31 \mathrm{~m}$ a.s.1.), Selangor, Malaysia, to determine weed suppressive ability of pre-emergence application of leaf powder and leaf methanol extract of T. crispa against three common rice weed species. The local climate is hot and humid. The average daily temperature was $30{ }^{\circ} \mathrm{C}$ and $81 \%$ RH.

Rice field soil was oven-dried $\left(70{ }^{\circ} \mathrm{C}\right.$ for $\left.72 \mathrm{~h}\right)$ to kill seeds and filled into pots (15 cm diameter $\times 12 \mathrm{~cm}$ height). Pre-germinated three common rice weed seeds, barnyard grass (E. crus-galli), weedy rice (O. sativa) and smallflower umbrella ( $C$. difformis), were seeded in the pots before covering with $1 \mathrm{~cm}$ soil and moistened with tap water. One day after sowing, leaf powder of T. crispa was applied at 1,2 and $4 \mathrm{t} \mathrm{ha}^{-1}$ by scattering the powder onto the soil surface, and 1000, 2000 and $4000 \mathrm{~L} \mathrm{ha}^{-1} T$. crispa leaf extract $(100 \% \mathrm{w} / \mathrm{v})$ were added into the pots. These dosages corresponded to $1.76,3.52,7.04 \mathrm{~g}$ leaf powder $\operatorname{pot}^{-1}$ and 1.76, $3.52,7.04 \mathrm{~mL}$ leaf extract $(100 \% \mathrm{w} / \mathrm{v}) \operatorname{pot}^{-1}$. Pots without $T$. crispa were used as control. The number of seeds per pot varied between 5 (barnyard grass), 5 (weedy rice), and 30 (small-flower umbrella sedge). Plants were harvested $45 \mathrm{~d}$ after sowing. Effect of treatments was measured on germination $(\%)$, plant height $(\mathrm{cm})$ and shoot and root dry weight $\left(\mathrm{g} \mathrm{pot}^{-1}\right)$ of weed species. Shoot and root samples were carefully separated and rinsed with water to remove soil debris. Shoot and root samples were oven-dried to a constant weight at $70{ }^{\circ} \mathrm{C}$ for $72 \mathrm{~h}$ and dry weight $\left(\mathrm{g} \mathrm{pot}^{-1}\right)$ was recorded.

\section{Foliar spray application of leaf methanol extract on selected rice weeds}

In another study, $T$. crispa methanol leaf extract was sprayed on 2-wk-old target weed species in the same condition (weeds, soil, pot, and environment). Five equalsized healthy 2-wk-old target weed species seedlings from a nursery were selected and transplanted into pots $(15 \mathrm{~cm}$ diameter $\times 12 \mathrm{~cm}$ height). One day after transplanting of 
seedlings, 0, 1000, 2000 and $4000 \mathrm{~L} \mathrm{ha}^{-1}$ (same doses used in the previous experiment) leaf methanol extract at $100 \%$ w/v was applied during four times of spraying. Leaf extract was sprayed at $1 \mathrm{wk}$ intervals at 250, 500 and $1000 \mathrm{~L} \mathrm{ha}^{-1}$ each time, using a common $1 \mathrm{~L}$ garden sprayer. Effect of treatments was measured as plant height $(\mathrm{cm})$ and shoot and root dry weight $\left(\mathrm{g} \mathrm{pot}^{-1}\right)$ of weed 1-mo after transplantation.

\section{Growth and grain yield of rice under pre- and post-emergence application of powder and extract of $T$. crispa leaves}

All treatments (powder and extract) were evaluated on growth and yield of transplanted rice ('MR219') to assess whether transplanted rice can tolerate these phytotoxic materials. Five uniform 1-mo-old rice seedlings from a nursery were selected and transplanted into pots $(25 \mathrm{~cm}$ diameter and $35 \mathrm{~cm}$ depth) in the glasshouse. The treatments were applied with the same method as we mentioned in the previous sections. The effect of treatments (pre-emergence application of leaf powder, pre-emergence and foliar applications of leaf extract) was measured on DW and grain yield of rice. The rice was harvested at full maturity (when $90 \%$ grains became golden yellow), and grain and straw biomass were recorded. Yield was adjusted at $12 \%$ water content. Water regime used in this study was continuous flooding at $5 \mathrm{~cm}$ depth. Treatments were replicated four times and arranged in a randomized complete block design. All pot experiments were repeated twice.

\section{Control potential of T. crispa leaf powder in rice field}

The field experiment was conducted in October 2014 at the experimental rice field, Faculty of Agriculture, Universiti Putra Malaysia, until July 2015. This region has a hot and humid climate with an average annual temperature of $27^{\circ} \mathrm{C}$ and an annual rainfall of $2500 \mathrm{~mm}$. The soil contains organic $\mathrm{C} 1.19 \%, \mathrm{pH} 6.2,18.1 \%$ sand, $37.5 \%$ silt and $44.4 \%$ clay at $0-20 \mathrm{~cm}$ depth.

The soil was ploughed, harrowed and puddled during preparation. The field was divided into 15 plots $(1 \mathrm{~m} \times 1 \mathrm{~m})$, arranged in a randomized complete block design (RCBD) with three replicates. Each plot was separated by $1 \mathrm{~m}$ width and $30 \mathrm{~cm}$ high levees. Both sides of the levee were covered with plastic mulch to prevent the movement of irrigation water and treatments to other plots. There was $1.0 \mathrm{~m}$ gap between plots.

Water regime used in this study was continuous flooding ( $5 \mathrm{~cm}$ water depth as recommended condition) until maturity. All plots received fertilizer (urea, triple super phosphate and muriate of potash at 10, 4 and 6 $\mathrm{g} \mathrm{m}^{-2}$ respectively) $1 \mathrm{~d}$ before seedling transplanting. The rice seedlings ( 1 mo-old) of common rice variety ('MR219') in Malaysia were transplanted in the plots at planting density of 30 plants $\mathrm{m}^{-2}$. One day after transplanting, different rates of leaf powder $(1,2$, and 4 $\mathrm{t} \mathrm{ha}^{-1}$ ) and chemical herbicide pretilachlor (2-chloro-2',6'- diethyl- $N$-(2-propoxyethyl)acetanilide) + pyribenzoxim (benzophenone $O$-[2,6-bis(4,6-dimethoxypyrimidin-2yloxy)benzoyl]oxime); Solito, Syngenta Corporation Sdn Bhd, Shah Alam, Selangor, Malaysia) (positive control) at recommended dose $\left(1 \mathrm{~L} \mathrm{ha}^{-1}\right)$ were applied to the plots. The negative control received neither plant powder nor chemical herbicide. Leaf powder of T. tuberculata was applied by scattering the powder onto soil surface.

Weed species were count in plots after physiological maturity of rice (90 d after transplanting). Number of weeds that emerged, their species and dry weight (biomass) were determined in each plot. Plant heights, straw dry weight, grain yield, major grain parameters, including number of grain per panicle, 1000 seeds weight of 15 rice plants at the mature stage in a $0.5 \mathrm{~m}^{2}$ area in the center of each plot were determined.

\section{Statistical analysis}

In the glasshouse and field experiments, treatments were arranged in a RCBD with four and three replicates, respectively. Both glasshouse and field experiments were repeated twice and mean values were pooled, because nonsignificant differences were observed between repeated experiments. An ANOVA was carried out using the PROC GLM procedure in SAS software (SAS 9.3, SAS Institute, Cary, North Carolina, USA) in order to determine any significant differences among treatments. Separation of treatment means from the control at 0.05 probability level was conducted using the LSD test, as outlined in the SAS procedure (version 9.3). Effective doses capable of inhibiting $50 \%$ of tested parameters were calculated as $\mathrm{EC}_{50}$. EC 50 values were calculated by Probit analysis based on percent of parameters inhibition. Ranking for each of the most effective compounds determined as an index $\left(\mathrm{R}_{\mathrm{e}}\right)$ using the following equation for each plant tested:

$$
\mathrm{R}_{\mathrm{e}}=\mathrm{EC}_{\mathrm{g} 50}(\text { germination })+\mathrm{EC}_{\mathrm{S} 50}(\text { shoot })+\mathrm{EC}_{\mathrm{r} 50}(\text { root })+
$$$$
\mathrm{EC}_{\mathrm{b} 50} \text { (biomass) }+\mathrm{EC}_{\mathrm{ph} 50} \text { (plant height) }
$$

where $R_{e}$ is the rank of the tested plants and the $\mathrm{EC}_{\mathrm{g} 50}$, $\mathrm{EC}_{\mathrm{S} 50}, \mathrm{EC}_{\mathrm{r} 50}, \mathrm{EC}_{\mathrm{b} 50}$ and $\mathrm{EC}_{\mathrm{ph} 50}$ are the concentrations of treatments that inhibits $50 \%$ germination, shoot growth, root growth, biomass and plant height of tested plants, respectively. The treatment with the lowest $R_{e}$ values is the most phytotoxic treatment.

\section{RESULTS}

\section{Phytotoxic effects of leaf powder and leaf methanol extract on germination and seedling growth of target weed species}

A study was done to determine whether the phytotoxic effects of T. crispa leaves would be maintained in soil. Powder and methanol extract of $T$. crispa leaves (at same doses of leaf material) were applied on pre-germinated seeds and 2-wk-old seedlings of target weed species and transplanted rice under glasshouse condition. The results show that application of powder and methanol extract of 
T. crispa leaves significantly reduced germination, shoot and root dry weight and plant height of tested weed species in comparison with the control and the inhibition degrees become larger with the increasing dose of treatments (Tables 1 and 2).

The inhibitory activity of leaf methanol extract and leaf powder of T. tuberculata was summarized as concentrations required for $50 \%$ growth inhibition $\left(\mathrm{EC}_{50}\right)$ (Table 3$)$. With these values, an index $\left(\mathrm{R}_{\mathrm{e}}\right)$ was calculated to determine the activity of treatments (either leaf powder or leaf extract), sensitivity of tested plants (barnyard grass, small-flower umbrella and weedy rice) and sensitivity of tested indices (germination, biomass, plant height, root and shoot growth).

The treatments (leaf powder and leaf extract) exhibited various degrees of growth inhibitory effects, as evaluated on their inhibition of the germination, biomass, plant height, root and shoot growth of the tested plants (Table 3 ). The $\mathrm{R}_{\mathrm{e}}$ of leaf powder (33.34) and leaf extract (42.39) for all plants and all indices showed that leaf powder was more potent, with a rank value approximately $21 \%$ lower compared to those of the leaf extract. The leaf powder had lower $\mathrm{EC}_{50}$ value of all measured parameters for all tested weed species except in the germination of small-flower umbrella sedge. The $\mathrm{R}_{\mathrm{e}}$ of leaf powder against barnyard grass, smallflower umbrella sedge and weedy rice was 10.84, 10.0, and 12.5, respectively, while for leaf extract was 13.60, 12.57 , and 16.22 , respectively (Table 3 ). These results indicate that the weed species growth was more affected by $T$. crispa leaf powder than leaf extract. In addition, these values show some differences among the plant response to the inhibitory effect of the powder and methanol extract of $T$. crispa leaves. Weedy rice was affected at higher concentrations (12.50 and 16.22 in leaf powder and leaf extract respectively) in comparison with other two weed species. Therefore, weedy rice showed more tolerance against treatments.

Analysis of the obtained $\mathrm{EC}_{50}$ also showed some differences among measured parameters (germination, biomass, plant height, root and shoot growth) to the inhibitory effect of applied treatments. Among the five tested indices, plant height was less affected and root growth and biomass were more sensitive to both leaf powder and leaf extract in comparison to the other tested indices (Table $3) . \mathrm{EC}_{50}$ for the plant height was more than the respective

Table 1. Effect of dried leaf powder of Tinospora crispa on the germination and growth of test weeds in the pots.

\begin{tabular}{|c|c|c|c|c|c|c|}
\hline Plant & Dose & Germination & Shoot dry weight & Root dry weight & Total biomass & Plant height \\
\hline & $\mathrm{t} \mathrm{ha}^{-1}$ & $\%$ & & $\mathrm{~g} \mathrm{pot}^{-1}$ & & $\mathrm{~cm}$ \\
\hline \multirow[t]{4}{*}{ Barnyard grass } & 0 & $90 \pm 5.7 \mathrm{a}(0)$ & $4.0 \pm 0.31 \mathrm{a}(0)$ & $2.9 \pm 0.18 \mathrm{a}(0)$ & $6.9 \pm 0.44 \mathrm{a}(0)$ & $58.1 \pm 1.6 \mathrm{a}(0)$ \\
\hline & 1 & $70 \pm 5.7 a(22.2)$ & $2.9 \pm 0.29 b(26.3)$ & $2.5 \pm 0.24 \mathrm{a}(14.3)$ & $5.4 \pm 0.41 b(21.3)$ & $46.1 \pm 1.6 b(20.7)$ \\
\hline & 2 & $30 \pm 5.7 b(66.6)$ & $1.4 \pm 0.32 c(62.8)$ & $1.0 \pm 0.09 b(64.7)$ & $2.5 \pm 0.37 \mathrm{c}(63.6)$ & $33.8 \pm 4.4 \mathrm{c}(41.8)$ \\
\hline & 4 & $15 \pm 5.0 \mathrm{~b}(83.3)$ & $0.5 \pm 0.10 \mathrm{~d}(86.9)$ & $0.2 \pm 0.05 \mathrm{c}(90.4)$ & $0.8 \pm 0.08 \mathrm{~d}(88.4)$ & $18.7 \pm 9.5 \mathrm{~d}(67.8)$ \\
\hline \multirow[t]{4}{*}{ Small-flower umbrella } & 0 & $79.1 \pm 1.5 \mathrm{a}(0)$ & $3.6 \pm 0.23 \mathrm{a}(0)$ & $2.8 \pm 0.78 \mathrm{a}(0)$ & $6.4 \pm 0.95 a(0)$ & $44.2 \pm 1.2 \mathrm{a}(0)$ \\
\hline & 1 & $75.8 \pm 2.8 \mathrm{a}(4.2)$ & $3.2 \pm 0.18 b(10.0)$ & $1.2 \pm 0.2 b(53.8)$ & $4.5 \pm 0.22 b(29.13)$ & $34.2 \pm 1.5 \mathrm{~b}(22.5)$ \\
\hline & 2 & $55.8 \pm 6.8 b(29.4)$ & $0.5 \pm 0.05 c(85.5)$ & $0.7 \pm 0.30 \mathrm{c}(72)$ & $1.3 \pm 0.35 c(79.61)$ & $22.2 \pm 1.6 \mathrm{c}(49.7)$ \\
\hline & 4 & $28.3 \pm 2.1 \mathrm{c}(48.4)$ & $0.3 \pm 0.04 \mathrm{~d}(91.1)$ & $0.2 \pm 0.06 \mathrm{~d}(91.6)$ & $0.5 \pm 0.05 \mathrm{~d}(91.3)$ & $12.2 \pm 0.85 \mathrm{~d}(72.3)$ \\
\hline \multirow[t]{4}{*}{ Weedy rice } & 0 & $90 \pm 5.7 \mathrm{a}(0)$ & $4.69 \pm 0.58 \mathrm{a}(0)$ & $3.0 \pm 0.67 \mathrm{a}(0)$ & $7.7 \pm 1.1 \mathrm{a}(0)$ & $13.2 \pm 0.75 \mathrm{a}(0)$ \\
\hline & 1 & $55 \pm 17.0 \mathrm{~b}(38.8)$ & $3.0 \pm 0.88 b(35.6)$ & $2.4 \pm 0.57 b(22.0)$ & $5.4 \pm 1.4 b(30.2)$ & $11.6 \pm 1.4 \mathrm{a}(12.0)$ \\
\hline & 2 & $40 \pm 8.1 \mathrm{bc}(55.5)$ & $2.4 \pm 0.49 b(47.9)$ & $1.3 \pm 0.40 \mathrm{c}(55.5)$ & $3.8 \pm 0.17 \mathrm{c}(50.9)$ & $9.1 \pm 0.32 \mathrm{ab}(30.6)$ \\
\hline & 4 & $15 \pm 5.0 \mathrm{c}(83.3)$ & $1.2 \pm 0.27 \mathrm{c}(73.6)$ & $0.1 \pm 0.05 \mathrm{~d}(95.5)$ & $1.3 \pm 0.27 \mathrm{~d}(82.3)$ & $6.4 \pm 3.5 b(51.13)$ \\
\hline
\end{tabular}

Note: Data are expressed as means \pm standard error. Means with the same letters in the column for each plant are not significantly different according to LSD at $\mathrm{p}<0.05$. Values inside the parenthesis are inhibition percentage over the control.

Table 2. Effect of leaf methanol extract of Tinospora crispa $(100 \% \mathrm{w} / \mathrm{v})$ on the germination and growth of test weeds in the pots.

\begin{tabular}{|c|c|c|c|c|c|c|}
\hline Plant & Dose & Germination & Shoot dry weight & Root dry weight & Total biomass & Plant height \\
\hline & $\mathrm{L} \mathrm{ha}^{-1}$ & $\%$ & & $\mathrm{~g} \mathrm{pot}^{-1}$ & & $\mathrm{~cm}$ \\
\hline \multirow[t]{4}{*}{ Barnyard grass } & 0 & $90 \pm 5.7 \mathrm{a}(0)$ & $4.0 \pm 0.31 \mathrm{a}(0)$ & $2.9 \pm 0.18 \mathrm{a}(0)$ & $6.9 \pm 0.44 \mathrm{a}(0)$ & $58.1 \pm 1.6 \mathrm{a}(0)$ \\
\hline & 1000 & $75 \pm 9.5 \mathrm{a}(16.6)$ & $3.9 \pm 0.31 \mathrm{a}(2.2)$ & $2.9 \pm 0.15 a(-0.3)$ & $6.8 \pm 0.29 a(1.2)$ & $48.6 \pm 4.2 b(16.3)$ \\
\hline & 2000 & $40 \pm 8.1 \mathrm{~b}(55.5)$ & $2.0 \pm 0.25 b(49.7)$ & $1.2 \pm 0.07 \mathrm{~b}(56.8)$ & $3.2 \pm 0.30 b(52.7)$ & $34.3 \pm 4.2 \mathrm{c}(41.0)$ \\
\hline & 4000 & $25 \pm 5.0 \mathrm{~b}(72.2)$ & $0.9 \pm 0.07 \mathrm{c}(75.9)$ & $0.7 \pm 0.05 \mathrm{c}(74.3)$ & $1.7 \pm 0.09 \mathrm{c}(75.2)$ & $21.7 \pm 1.9 \mathrm{~d}(62.7)$ \\
\hline \multirow[t]{4}{*}{ Small-flower umbrella } & 0 & $79.1 \pm 1.5 \mathrm{a}(0)$ & $3.6 \pm 0.23 \mathrm{a}(0)$ & $2.8 \pm 0.78 \mathrm{a}(0)$ & $6.4 \pm 0.95 \mathrm{a}(0)$ & $44.2 \pm 1.2 \mathrm{a}(0)$ \\
\hline & 1000 & $65 \pm 2.1 \mathrm{~b}(17.8)$ & $3.6 \pm 1.3 \mathrm{a}(0)$ & $1.9 \pm 0.41 \mathrm{~b}(30.0)$ & $5.6 \pm 1.0 \mathrm{~b}(12.4)$ & $42.5 \pm 2.3 \mathrm{a}(3.9)$ \\
\hline & 2000 & $46.6 \pm 3.0 \mathrm{c}(41.0)$ & $1.2 \pm 0.23 b(65.8)$ & $1.1 \pm 0.53 \mathrm{c}(59.2)$ & $2.3 \pm 0.66 \mathrm{c}(62.9)$ & $20.5 \pm 1.5 b(53.6)$ \\
\hline & 4000 & $30.8 \pm 2.8 \mathrm{~d}(61.0)$ & $0.6 \pm 0.08 b(83.3)$ & $0.3 \pm 0.08 \mathrm{~d}(87.4)$ & $0.9 \pm 0.15 \mathrm{~d}(85.1)$ & $27.5 \pm 2.2 \mathrm{c}(37.8)$ \\
\hline \multirow[t]{4}{*}{ Weedy rice } & 0 & $90 \pm 5.7 \mathrm{a}(0)$ & $4.69 \pm 0.58 \mathrm{a}(0)$ & $3.0 \pm 0.67(0)$ & $7.7 \pm 1.1 \mathrm{a}(0)$ & $13.2 \pm 0.75 \mathrm{a}(0)$ \\
\hline & 1000 & $80 \pm 0.0 \mathrm{a}(11.1)$ & $5.3 \pm 0.57 b(-14.8)$ & $2.7 \pm 0.74 \mathrm{a}(9.7)$ & $8.1 \pm 0.0 \mathrm{ab}(-5.0)$ & $9.7 \pm 1.0 \mathrm{a}(26.3)$ \\
\hline & 2000 & $50 \pm 0.0 \mathrm{~b}(44.4)$ & $4.4 \pm 0.40 \mathrm{~b}(4.4)$ & $2.6 \pm 0.40 \mathrm{a}(13.3)$ & $7.1 \pm 0.0 \mathrm{~b}(7.9)$ & $11.7 \pm 0.27 \mathrm{ab}(10.9)$ \\
\hline & 4000 & $20 \pm 0.0 \mathrm{c}(77.7)$ & $1.4 \pm 0.12 c(69.2)$ & $0.2 \pm 0.06 b(92.2)$ & $1.6 \pm 0.0 \mathrm{c}(78.3)$ & $6.5 \pm 3.6 b(50.56)$ \\
\hline
\end{tabular}

Note: Data are expressed as means \pm standard error. Means with the same letters in the column for each plant are not significantly different according to LSD at $\mathrm{p}<0.05$. Values inside the parenthesis are inhibition percentage over the control. 
Table 3. Effective concentration $\left(\mathrm{EC}_{50}\right)$ for germination $\left(\mathrm{EC}_{\mathrm{g50}}\right)$, shoot dry weight $\left(\mathrm{EC}_{\mathrm{s} 50}\right)$, root dry weight $\left(\mathrm{EC}_{\mathrm{r} 50}\right)$, total biomass $\left(\mathbf{E C}_{\mathrm{b50}}\right)$, and plant height $\left(\mathrm{EC}_{\mathrm{ph50}}\right)$ of selected weed species exposed to leaf powder and leaf methanol extract (pre-emergence and foliar spray) of Tinospora crispa in glasshouse condition.

\begin{tabular}{|c|c|c|c|c|c|c|}
\hline \multirow[b]{2}{*}{ Target plants } & \multicolumn{5}{|c|}{ Leaf powder $\left(\mathrm{t} \mathrm{ha}^{-1}\right)$} & \multirow{2}{*}{$\begin{array}{c}\text { Rank } \\
\left(\mathrm{R}_{\mathrm{e}}\right) \\
\end{array}$} \\
\hline & $\mathrm{EC}_{\mathrm{g} 50}$ & $\mathrm{EC}_{\mathrm{S} 50}$ & $\mathrm{EC}_{\mathrm{r} 50}$ & $\mathrm{EC}_{\mathrm{b} 50}$ & $\mathrm{EC}_{\mathrm{ph} 50}$ & \\
\hline Barnyard grass & 2.08 & 2.02 & 2.00 & 2.04 & 2.70 & 10.84 \\
\hline Small-flower umbrella & 3.00 & 1.50 & 1.50 & 1.50 & 2.50 & 10.00 \\
\hline Weedy rice & 2.20 & 2.40 & 2.00 & 2.20 & 3.70 & 12.50 \\
\hline \multirow[t]{3}{*}{ Rank } & 7.28 & 5.92 & 5.50 & 5.74 & 8.90 & 33.34 \\
\hline & \multicolumn{5}{|c|}{ Leaf methanol extract $\left(1000 \mathrm{~L} \mathrm{ha}^{-1}\right)$} & \multirow{2}{*}{$\begin{array}{c}\text { Rank } \\
\left(\mathrm{R}_{\mathrm{e}}\right)\end{array}$} \\
\hline & $\mathrm{EC}_{\mathrm{g} 50}$ & $\mathrm{EC}_{\mathrm{S} 50}$ & $\mathrm{EC}_{\mathrm{r} 50}$ & $\mathrm{EC}_{\mathrm{b} 50}$ & $\mathrm{EC}_{\mathrm{ph} 50}$ & \\
\hline Barnyard grass & 2.40 & 2.60 & 2.50 & 2.60 & 3.50 & 13.60 \\
\hline Small-flower umbrella & 2.53 & 2.30 & 2.02 & 2.18 & 3.54 & 12.57 \\
\hline Weedy rice & 2.64 & 3.54 & 2.73 & 3.28 & 4.03 & 16.22 \\
\hline \multirow[t]{3}{*}{ Rank } & 7.57 & 8.44 & 7.25 & 8.06 & 11.07 & 42.39 \\
\hline & \multicolumn{5}{|c|}{ Leaf methanol extract (1000 L ha-1) (foliar spray) } & \multirow{2}{*}{$\begin{array}{c}\operatorname{Rank} \\
\left(\mathrm{R}_{\mathrm{e}}\right)\end{array}$} \\
\hline & $\mathrm{EC}_{\mathrm{g} 50}$ & $\mathrm{EC}_{\mathrm{S} 50}$ & $\mathrm{EC}_{\mathrm{r} 50}$ & $\mathrm{EC}_{\mathrm{b} 50}$ & $\mathrm{EC}_{\mathrm{ph} 50}$ & \\
\hline Barnyard grass & - & 6.19 & 10.63 & 7.79 & 4.93 & 29.54 \\
\hline Small-flower umbrella & - & 5.39 & 6.47 & 6.35 & 3.53 & 21.74 \\
\hline Rank & - & 11.58 & 17.10 & 14.14 & 8.46 & 51.28 \\
\hline
\end{tabular}

$\mathrm{EC}_{\mathrm{g} 50}, \mathrm{EC}_{\mathrm{s} 50}, \mathrm{EC}_{\mathrm{r} 50}, \mathrm{EC}_{\mathrm{b} 50}$ and $\mathrm{EC}_{\mathrm{ph} 50}$ are the concentrations of extracts that inhibits $50 \%$ of germination, shoot, root, biomass and plant height, respectively.

values for other parameters for all tested plants in both leaf powder and leaf extract except in germination of smallflower umbrella sedge.

Overall, leaf powder of T. crispa produced significantly higher phytotoxic effect, especially to root and biomass, which were inhibited at the lowest concentration (Table 3).

\section{Foliar-spray pot experiment (post- emergence application)}

Data regarding the effect of foliar spray of methanol leaf extract of T. crispa on plant height and aboveground dry weight of tested weeds is presented in Figure 1. Biomass and plant height of treated weeds were measured at $6 \mathrm{wk}$ after sowing. Results showed nonsignificant reduction in root dry weight, aboveground dry weight production and plant height of weedy rice, indicating that methanol extract did not decrease growth of weedy rice as post-emergence herbicide.

In the case of barnyard grass, only $1000 \mathrm{~L} \mathrm{ha}^{-1}$ significantly decreased plant height and aboveground dry weight compared with the control. This treatment decreased plant height and aboveground dry weight by $45 \%$ and $34 \%$, respectively, in comparison with control (Figure 1).

All the treatments significantly reduced aboveground dry weight and plant height of small-flower umbrella, compared with the control. Plant height of small-flower umbrella was reduced by $18 \%, 19 \%$ and $59 \%$ and the reduction of aboveground dry weight was $4 \%, 6 \%$ and $40 \%$ of control in 250, 500 and $1000 \mathrm{~L} \mathrm{ha}^{-1}$ spray volume of methanol leaf extract $(100 \% \mathrm{w} / \mathrm{v})$, respectively (Figure 1$)$.

$\mathrm{EC}_{50}$ values for the post-emergence application of leaf methanol extract on straw dry weight, root dry weight, total biomass and plant height of barnyard grass were 6190 , 10630,7790 and $4930 \mathrm{~L} \mathrm{ha}^{-1}$ and for small-flower umbrella sedge were $5390,6470,6350$ and $3530 \mathrm{~L} \mathrm{ha}^{-1}$, respectively. In general, $\mathrm{EC}_{50}$ values of target weed species were higher than applied doses $\left(>4000 \mathrm{~L} \mathrm{ha}^{-1}\right)$. Therefore, leaf extract was less active when applied as post-emergence inhibitor and the $\mathrm{EC}_{50}$ values could be different (Table 3 ).

Figure 1. Effect of foliar-applied Tinospora crispa leaf methanol extract on the growth of barnyard grass, smallflower umbrella and weedy rice.
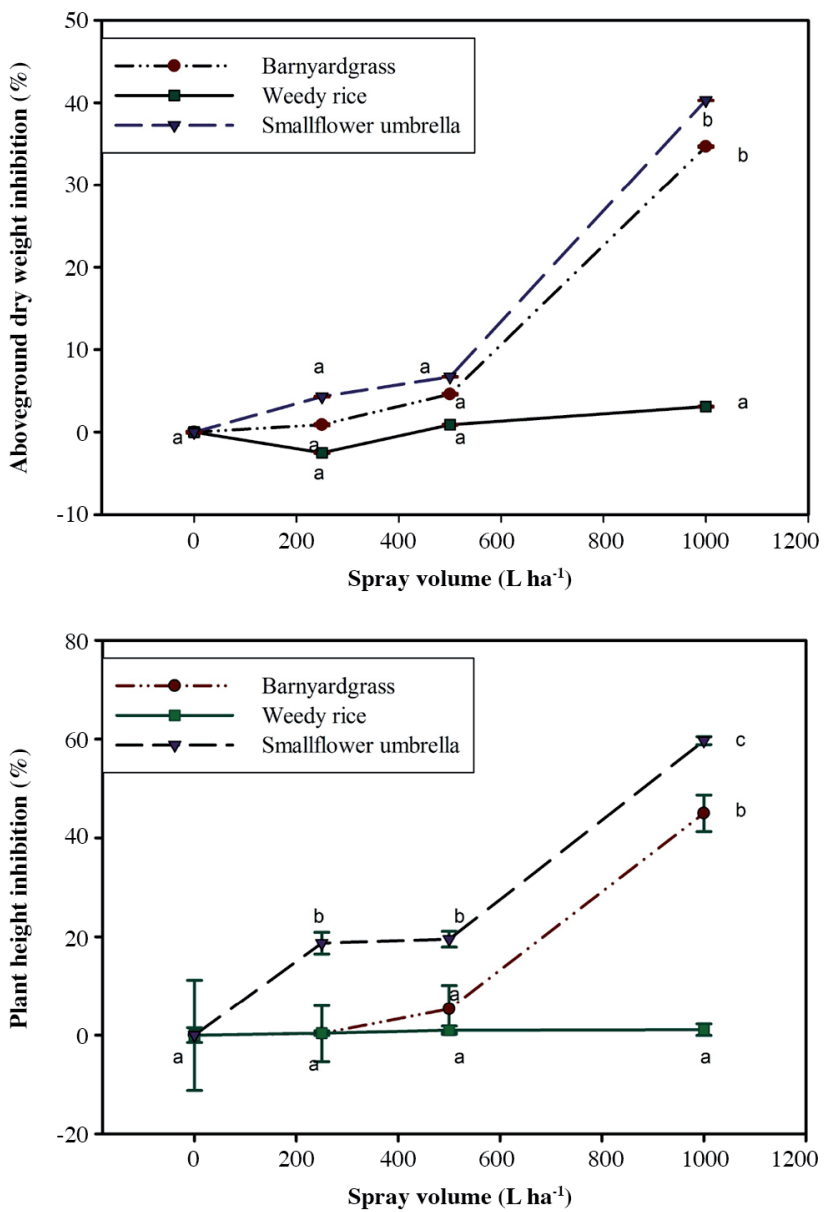


\section{Responses of growth and grain yield of transplanted rice to the treatments}

Pre-emergence and foliar spray applications of leaf powder and leaf extract were also evaluated on the development of transplanted rice plants. Data on the plant height, straw dry weight and grain yield were recorded to assess whether transplanted rice can tolerate these phytotoxic materials (Table 4).

These results showed that not only there were no inhibitory effects on plant height; straw dry weight and grain yield; even powder and extract of leaves (only at highest dose) could promote grain yield of rice plants relative to the control pots.

\section{Application of leaf powder in rice field}

There are some variable factors in the field including climatic conditions, presence of other plant species, soil conditions, which may affect alleopathic effects of T. crispa. Thus, a field study was done to validate the suppressive ability of T. crispa leaf powder under actual rice field conditions.

In the field, utilization of leaf powder of $T$. crispa leads to a satisfactory weed control as it significantly reduced both the number and the dry weight of all weed species. In the weedy control, seven rice weed species including

Table 4. Leaf powder (pre-emergence), leaf extract (preemergence) and foliar spray of leaf extract on the development and grain yield of transplanted rice in the glasshouse condition.

\begin{tabular}{|c|c|c|c|}
\hline \multirow[b]{3}{*}{$\begin{array}{l}\text { Leaf powder } \\
\text { (pre-emergence), } \mathrm{t} \mathrm{ha}^{-1}\end{array}$} & Grain yield & $\begin{array}{l}\text { Aboveground } \\
\text { dry weight }\end{array}$ & \multirow{2}{*}{$\begin{array}{c}\text { Plant height } \\
\mathrm{cm}\end{array}$} \\
\hline & & $a^{-1}$ & \\
\hline & & & \\
\hline 0 & $8.3 \pm 0.18 a$ & $10.2 \pm 1.45 \mathrm{a}$ & $57.6 \pm 0.11 \mathrm{a}$ \\
\hline 1 & $8.3 \pm 0.28 \mathrm{a}$ & $10.1 \pm 1.20 \mathrm{a}$ & $55.3 \pm 0.23 a$ \\
\hline 2 & $8.1 \pm 0.19 a$ & $10.3 \pm 1.45 \mathrm{a}$ & $56.6 \pm 0.07 a$ \\
\hline 4 & $9 \pm 0.09 b$ & $10.6 \pm 1.20 \mathrm{a}$ & $57.3 \pm 0.015$ \\
\hline \multicolumn{4}{|c|}{$\begin{array}{l}\text { Leaf extract } \\
\text { (pre-emergence), } \mathrm{L} \mathrm{ha}^{-1}\end{array}$} \\
\hline 0 & $8.3 \pm 0.26 a$ & $10.2 \pm 1.66 a$ & $57.6 \pm 0.18 a$ \\
\hline 1000 & $8.2 \pm 0.22 a$ & $10.4 \pm 1.45 \mathrm{a}$ & $55.6 \pm 0.16 \mathrm{a}$ \\
\hline 2000 & $8.4 \pm 0.22 a$ & $10.4 \pm 1.52 \mathrm{a}$ & $57 \pm 0.20 \mathrm{a}$ \\
\hline 4000 & $9.1 \pm 0.09 b$ & $10.7 \pm 3.05 \mathrm{a}$ & $57 \pm 0.07 a$ \\
\hline \multicolumn{4}{|c|}{$\begin{array}{l}\text { Leaf extract } \\
\text { (foliar spray), } \mathrm{L} \mathrm{ha}^{-1}\end{array}$} \\
\hline 0 & $8.3 \pm 0.21 \mathrm{a}$ & $10.2 \pm 1.85 \mathrm{a}$ & $57.6 \pm 0.12 a$ \\
\hline 1000 & $8.3 \pm 0.12 a$ & $10.3 \pm 1.76 a$ & $57.6 \pm 0.19 a$ \\
\hline 2000 & $8.4 \pm 0.23 a$ & $10.2 \pm 2.30 \mathrm{a}$ & $58.3 \pm 0.11 a$ \\
\hline 4000 & $8.1 \pm 0.21 \mathrm{a}$ & $10.3 \pm 1.45 \mathrm{a}$ & $58.6 \pm 0.16 a$ \\
\hline
\end{tabular}

Note: Data are expressed as means \pm SE. Means with the same letters in the column are not significantly different according to LSD at $\mathrm{p}<0.05$.
Cyperus difformis L., Cyperus iria L., Fimbristylis littoralis Gaudich., Dinebra chinensis (L.) P.M. Peterson \& N. Snow, Actinoscirpus grossus (L.f.) Goetgh. \& D.A. Simpson var. grossus, and Monochoria vaginalis (Burm. f.) C. Presl ex Kunth were observed. Application of leaf powder at $1 \mathrm{tha}^{-1}$ completely controlled emergence of $F$. littoralis and $M$. vaginalis. Dinebra chinensis, and $C$. difformis were totally controlled in those plots received $2 \mathrm{t} \mathrm{ha}^{-1}$ leaf powder.

The leaf powder at $1 \mathrm{t} \mathrm{ha}^{-1}$ reduced total weed seedling density from 53 to 14 plants per $\mathrm{m}^{2}$. Increasing the concentration of leaf powder to $2 \mathrm{t} \mathrm{ha}^{-1}$ remarkably enhanced the phytotoxic effect and reduced weed number up to 3 plants per $\mathrm{m}^{2}$. Finally, on average, less than one weed was observed per $\mathrm{m}^{2}$ treated with $4 \mathrm{t} \mathrm{ha}^{-1}$ leaf powder and pretilachlor + pyribenzoxim at full recommended dose rate (Table 5).

Biomass of the emerged weed plants also was reduced in plots receiving leaf powder treatment. In plots amended with 1,2 , and $4 \mathrm{t} \mathrm{ha}^{-1}$ leaf powder, weed dry weight was reduced by nearly $80 \%, 97 \%$ and $99 \%$ compared to untreated control plots (Table 5). There was nonsignificant difference between leaf powder-treated plots ( 2 and $\left.4 \mathrm{tha}^{-1}\right)$ and plots that received herbicidal treatment in percentage reduction of germination and dry weight of weeds.

The treatments had no effect on plant height and 1000 seed weight of rice. The leaf powder remarkably increased the number of seeds per panicle, straw dry weight and grain yield relative to the negative control and near to positive control plots (pretilachlor + pyribenzoxim at full recommended dose) (Table 6).

The alleviation of weed stress due to application of 1,2, and $4 \mathrm{tha}^{-1}$ leaf powder and chemical herbicide provided a significant $(\mathrm{P}<0.05)$ increase in rice grain yield by $11.4 \%, 11.7 \%, 14.8 \%$, respectively. In the case of straw dry weight, leaf powder induced an increasing of $7.9 \%, 12 \%$, $16 \%$, and $14.5 \%$ at 1,2 , and $4 \mathrm{t} \mathrm{ha}^{-1}$ leaf powder and full recommended dose of chemical herbicide (Table 6).

Number of seed per panicle was not significantly affected by leaf powder at $1 \mathrm{tha}^{-1}$. Weed stress was reduced significantly by exposure to 2 and $4 \mathrm{t} \mathrm{ha}^{-1}$ leaf powder and number of seed per panicle enhanced by $19.3 \%$ and $21 \%$ (P $<0.05$ ), respectively. There was an increase of $21.9 \%$ in the case of chemical herbicide compared with control. At 2 and $4 \mathrm{t} \mathrm{ha}^{-1}$, number of seed per panicle was nonsignificantly different with positive control plots with chemical herbicide application (Table 6). In general, a highly significant potential of leaf powder to reduce germination and dry weight of weeds with an increase in transplanted rice growth and yield was recorded.

Table 5. Effects of leaf powder of Tinospora crispa applied into the soil on the emergence and growth of rice weeds.

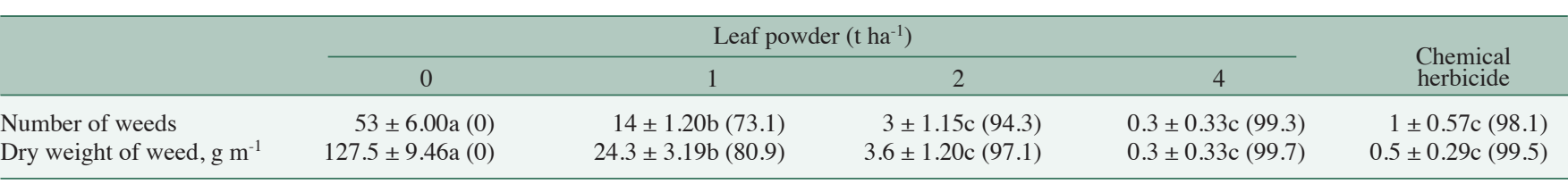

Note: Data are expressed as means \pm SE. Means with the same letters in the row are not significantly different according to LSD at $p<0.05$. Values inside the parenthesis are inhibition percentage over weedy control. 
Table 6. Effects of leaf powder of Tinospora crispa on the yield and yield components of transplanted rice.

\begin{tabular}{|c|c|c|c|c|c|}
\hline & \multicolumn{4}{|c|}{ Leaf powder $\left(\mathrm{t} \mathrm{ha}^{-1}\right)$} & \multirow{2}{*}{$\begin{array}{l}\text { Chemical } \\
\text { herbicide }\end{array}$} \\
\hline & 0 & 1 & 2 & 4 & \\
\hline Grain yield, $\mathrm{t} \mathrm{ha}^{-1}$ & $5.04 \pm 0.122 \mathrm{a}(0)$ & $5.61 \pm 0.106 b(11.4)$ & $5.63 \pm 0.138 b(11.7)$ & $5.78 \pm 0.107 b(14.8)$ & $5.73 \pm 0.132 b(13.8)$ \\
\hline Straw dry weight, $\mathrm{t} \mathrm{ha}^{-1}$ & $5.98 \pm 0.151 \mathrm{a}(0)$ & $6.46 \pm 0.068 b(7.9)$ & $6.70 \pm 0.084 \mathrm{bc}(12.0)$ & $6.94 \pm 0.047 \mathrm{c}(16.0)$ & $6.85 \pm 0.079 \mathrm{c}(14.5)$ \\
\hline 1000 seed weight, g & $22.8 \pm 0.046 \mathrm{a}(0)$ & $23.2 \pm 0.106 \mathrm{a}(1.4)$ & $23.8 \pm 0.037 \mathrm{a}(4.2)$ & $23.5 \pm 0.037 \mathrm{a}(2.9)$ & $23.7 \pm 0.078 \mathrm{a}(3.8)$ \\
\hline Number of seed per panicle & $115 \pm 2.330 \mathrm{a}(0)$ & $128 \pm 5.360 \mathrm{ab}(11.2)$ & $138 \pm 4.040 \mathrm{~b}(19.3)$ & $140 \pm 2.080 \mathrm{~b}(21.0)$ & $141 \pm 1.520 b(21.9)$ \\
\hline Plant height, $\mathrm{cm}$ & $74.66 \pm 2.400 \mathrm{a}(0)$ & $72.66 \pm 2.400 \mathrm{a}(2.6)$ & $73.33 \pm 2.020 \mathrm{a}(1.7)$ & $72.33 \pm 1.760 \mathrm{a}(3.1)$ & $74.33 \pm 2.020 \mathrm{a}(0.4)$ \\
\hline
\end{tabular}

Note: Data are expressed as means \pm SE. Means with the same letters in the row is not significantly different according to LSD at $\mathrm{p}<0.05$. Values inside the parenthesis are increasing percentage over weedy control.

\section{DISCUSSION}

Phytotoxic potential of T. crispa leaves was evaluated by testing its methanol extract and powder on rice yield and germination, seedling length and biomass production of associated weeds under both glasshouse and field condition. Phytotoxic activity of T. crispa leaves varied with application methods (powder and extract), time of application (pre- and post-emergence), concentration and recipient species.

The findings showed that both methods of application resulted in significant inhibition on the germination and growth of target seedlings. Seal et al. (2010) observed that irrigation with aqueous extract of Wollemi pine (Wollemia nobilis W.G. Jones et al.) reduced $25 \%$ of dry weight of annual ryegrass (Lolium rigidum Gaudin). Similarly, powder extract of water hyacinth (Eichhornia crassipes [Mart.] Solms.) is promising for soil additives to control barnyard grass with powder-concentration dependently in the greenhouse condition (Kato-Noguchi et al., 2014b). Kobayashi and Kato-Noguchi (2015) also reported that Brachiaria brizantha has enough potential to suppress weed species as soil additive materials and decrease chemical herbicide use.

Our filter paper experiment revealed that the extent of inhibition of leaf methanol extract was more than leaf water extract on the germination and growth of target plants. In contrast to the filter paper experiment, leaf powder was more potent relative to leaf methanol extract in the soil condition (Table 3). This is to be expected due to the myriad influences of abiotic and biotic factors in the soil such as microbial breakdown and transformation, leaching, and adsorption onto soil particles (Omezzine et al., 2011). Phytotoxic substances of leaf extract may have denatured in the soil, but they are released gradually from leaf powder and take more time to be decomposed.

The findings also recorded a huge difference in the times of leaf extract application. Comparison between foliar spray and pre-emergence application of a leaf extract showed the weed control in pre-emergence application of leaf extract was much more effective. Foliar spray was not able to inhibit $50 \%$ of weed species growth. Maximum reduction $(40 \%)$ was observed in plant height of smallflower umbrella.

In general, effectiveness of all applied treatments at equal rates and similar conditions on the germination and growth of target weed species could be arranged in the following order: leaf powder > pre-emergence application of leaf extract $>$ foliar spray of leaf extract. Laosinwattana et al. (2009) reported that leaf powder of Aglaia odorata Lour. was inhibitor to the germination and seedling growth of barnyard grass and wild pea (Phaseolus lathyroides L.) than aqueous extract.

The overall effect was found to be dosage dependent. The magnitude of inhibition increased with an increase in dose of leaf powder and leaf extract. This effect is likely to be due to the release of allelochemicals from phytotoxic material added into the soil (de Bertoldi et al., 2012).

Analysis of $\mathrm{EC}_{50}$ results indicated that weedy rice was only affected at higher concentrations of leaf extract and leaf powder as compared to barnyard grass and smallflower umbrella sedge. Therefore, it was apparent that different concentrations were needed to suppress different plants species. There are several reasons for the different sensitivity of various plant species to inhibitory compounds. It could be due to the physiological and biochemical characteristics of each species (Kobayashi, 2004), seed structure, seed coat penetrability and seed size (Machado, 2007). Sodaeizadeh et al. (2010) found that Avena fatua L. and Convolvulus arvensis L. varied in their sensitivity to Peganum harmala L.

Comparison of the rank values $\left(\mathrm{R}_{\mathrm{e}}\right)$ of both leaf powder and leaf extract (pre-emergence) on measured growth factors indicated that root growth and total biomass were more sensitive than the other parameters. The stronger harmful impacts of phytotoxic material on root growth could be explained by higher absorption in magnitude of phytotoxic substances by radicles, in close contact with phytotoxins (Tefera, 2002) and more permeable to phytotoxic compounds (Nishida et al., 2005).

Laboratory bioassays have already been done (Aslani et al., 2013; 2014; 2015) to show phytotoxic potential of $T$. crispa against different weed species, but there are different environmental parameters that can affect the inhibitory magnitude of phytotoxic materials in the actual field. In spite that, little effort has been made to investigate the relevance of results from laboratory experiments in field settings (Inderjit and Weston, 2000). Field study is necessary to provide strong evidence for allelopathy (Inderjit and Weston, 2000), to confirm laboratory results, and to transfer the results from bioassays to field (de Bertoldi et al., 2012). Therefore, a field study used natural paddy field, 
typical climatic and fertility features has been conducted to confirm the findings of previous studies.

The results might depend on the composition of the seed bank in the field soil. Since no weed seedbank determination was done in the field's soil, composition and density of weed seeds in the field is unknown. However, it is believed that those that germinated in the field were the most dominant weed species. It is more difficult to control dominant weed species, because they have more seed in the soil seed bank. In addition, the inhibition magnitude of applied treatment is species dependent.

Such an inhibitory effect of applied treatments on rice field weeds is useful, if growth and yield of rice is not affected. The glasshouse and field findings showed no negative effect on the growth of the transplanted rice (Tables 4 and 6). This result indicated that T. crispa leaves did not contain harmful allelochemicals for transplanted rice growth, but significantly inhibited the germination and biomass of weeds.

The possible reason may be the age difference of weed and rice seedlings at the time of application. Treatments were applied after transplanting of rice seedlings (1mo old), at that stage, rice seedlings are quite strong and therefore are able to withstand any possible inhibitory effects. Furthermore, the earlier results indicated that the inhibition magnitude of treatments was species dependent. Taxonomic variability of weed and host crop could possibly be another attribute for differential behavior to allelopathic effects (Anjum and Bajwa, 2007).

Reduction of rice-weed competition could be the main factor attributed to rice yield improvement treated with leaf powder and chemical herbicide compared with weedy control (Hong et al., 2004). Batish et al. (2007a) noted that the observed increase in rice yield with Tagetes minuta mulch incorporation may also be partly attributed to pesticidal properties of T. minuta against a variety of pests. Similarly, Khanh et al. (2006) used $2 \mathrm{t} \mathrm{ha}^{-1}$ dry plant materials of passion fruit (Passiflora edulis) to suppress the rice weeds in field condition. They observed a weed biomass reduction by $70 \%$ and rice yield increase by $35 \%$ compared to the weedy control. However, reports are available regarding utilization of medicinal plant mulch for weed control in wheat field with affecting wheat yield (Batish et al., 2007b). They observed Anisomeles indica at doses of 4 and $6 \mathrm{t} \mathrm{ha}^{-1}$ decreased dry weight and grain yield of wheat, in spite of the decrease in weed emergence and dry weight.

The efficacy of leaf powder was also compared with synthetic herbicides to validate the results. Nonsignificant differences were found between the impact of leaf powder at the applied concentrations and commercial herbicide at recommended dose $\left(1 \mathrm{~L} \mathrm{ha}^{-1}\right)$ on the rice yield and straw. Growth reduction of weeds resulted in more available nutrients in soil relative to the treatment without any weed management (Hong et al., 2004). This finding agrees with previous research, which reported that rice yield increased $28 \%$ and $23 \%$ in comparison with weedy control when used
Desmodium triflorum and Clerodendrum trichotomum dry material, respectively. Xuan et al. (2003) used two alfalfa varieties, namely 'Rasen' and 'Yuba' for weed control in rice field, findings indicated that 'Rasen' had a maximum increase in rice yield compared to the control.

\section{CONCLUSIONS}

The use of natural herbicides of plant origin besides enhancing crops production can be an alternative method for weed management in sustainable agriculture systems. The findings confirm the phytotoxic potential of Tinospora crispa leaves, depending on application methods (powder and extract), time of application (pre- and post-emergence), dose and recipient species. Leaf powder was found to have greater suppressive property than the leaf extract and the pre-emergence application of leaf extract showed higher phytotoxic activity compared with respective post-emergence application. The sensitivity of tested plants to all treatments appeared in the order of small-flower umbrella $>$ barnyard grass $>$ weedy rice. Treatments had no inhibitory effects on growth and development of transplanted rice plants at maturity stage, even grain yield of rice plants growing in both pots and field were promoted compared to weedy controls. Field study revealed a significant potential of leaf powder to reduce germination and dry weight of weeds, with a parallel increase in growth and yield of transplanted rice. These results, together with those achieved with previous studies, provide strong evidences for the phytotoxicity of these plant materials and potential for managing the rice field weeds. However, their effects on natural enemies and environment have not been fully investigated.

\section{ACKNOWLEDGEMENTS}

The authors sincerely acknowledge Long-term Research Grant Scheme (LRGS), Food Security Project, Ministry of Higher Education, Malaysia (5525001) and Fundamental Research Grant Scheme (07-01-13-1241FR) for financial support of the project.

\section{REFERENCES}

Anjum, T., and R. Bajwa. 2007. Field appraisal of herbicide potential of sunflower leaf extract against Rumex dentatus. Field Crops Research 100:139-142.

Alias, E.F., F.M. Arshad, K.M. Noh, and M. Tasrif. 2011. Food security: Self-sufficiency of rice in Malaysia. International Journal of Management Studies 18:83-100.

Aslani, F., A.S. Juraimi, M.S. Ahmad-Hamdani, D. Omar, and M.A. Alam. 2013. Allelopathic effects of Batawali (Tinospora tuberculata) on germination and seedling growth of plants. Research on Crops 14:1222-1231.

Aslani, F., A.S. Juraimi, M.S. Ahmad-Hamdani, D. Omar, M.A. Alam, and F.S.G. Hashemi. 2014. Allelopathic effect of methanol extracts from Tinospora tuberculata on selected crops and rice weeds. Acta Agriculturae Scandinavica, Section B-Soil \& Plant Science 64:165-177. 
Aslani, F., A.S. Juraimi, M.S. Ahmad-Hamdani, D. Omar, M.A. Alam, F.S.G. Hashemi, et al. 2015. Phytotoxic interference of volatile organic compounds and water extracts of Tinospora tuberculata Beumee on growth of rice weeds in rice fields. South African Journal of Botany 100:132-140.

Batish, D.R., K. Arora, H.P. Singh, and R.K. Kohli. 2007a. Potential utilization of dried powder of Tagetes minuta as a natural herbicide for managing rice weeds. Crop Protection 26:566-571.

Batish, D.R., M. Kaur, H.P. Singh, and R.K. Kohli. 2007b. Phytotoxicity of a medicinal plant Anisomeles indica, against Phalaris minor and its potential use as natural herbicide in wheat fields. Crop Protection 26:948-952.

Beltran, J.C., D.J. Pannell, G.J. Doole, and B. White. 2012. A bioeconomic model for analysis of integrated weed management strategies for annual barnyardgrass (Echinochloa crus-galli complex) in Philippine rice farming systems. Agricultural Systems 112:1-10.

Dadkhah, A. 2013. Phytotoxic potential of sugar beet (Beta vulgaris) and eucalyptus (Eucalyptus camaldulensis) to control purslane (Portulaca oleracea) weed. Acta Agriculturae Scandinavica, Section B-Soil \& Plant Science 63:46-51.

de Bertoldi, C., M. De Leo, L. Ercoli, and A. Braca. 2012. Chemical profile of Festuca arundinacea extract showing allelochemical activity. Chemoecology 22:13-21.

Forman, L. 1981. A revision of Tinospora (Menispermaceae) in Asia to Australia and the Pacific: The Menispermaceae of Malesia and adjacent areas: X. Kew Bulletin 375-421.

Gnanamanickam, S.S. 2009. Biological control of rice diseases. Springer, London, UK.

Haq, R.A., M. Hussain, Z.A. Cheema, M.N. Mushtaq, and M. Farooq. 2010. Mulberry leaf water extract inhibits bermudagrass and promotes wheat growth. Weed Biology and Management $10: 234-240$

Hong, N.H., T.D. Xuan, T. Eiji, and T.D. Khanh. 2004. Paddy weed control by higher plants from Southeast Asia. Crop Protection 23:255-261.

Inderjit, and L.A. Weston. 2000. Are laboratory bioassays for allelopathy suitable for prediction of field responses? Journal of Chemical Ecology 26:2111-2118.

Jabran, K., G. Mahajan, V. Sardana, and B.S. Chauhan. 2015. Allelopathy for weed control in agricultural systems. Crop Protection 72:57-65.

Kato-Noguchi, H., N. Hamada, M. Morita, and K. Suenaga, 2013. A novel allelopathic substance, 13-epi-orthosiphol N, in Orthosiphon stamineus. Journal of Plant Physiology 170:1-5.

Kato-Noguchi, H., M. Moriyasu, O. Ohno, and K. Suenaga. 2014b. Growth limiting effects on various terrestrial plant species by an allelopathic substance, loliolide, from water hyacinth. Aquatic Botany 117:56-61.

Kato-Noguchi, H., P. Pukclai, O. Ohno, and K. Suenaga. 2014a. Isolation and identification of a plant growth inhibitor from Tinospora tuberculata Beumee. Acta Physiologiae Plantarum 36:1621-1626.

Khanh, T., I. Chung, S. Tawata, and T. Xuan. 2006. Weed suppression by Passiflora edulis and its potential allelochemicals. Weed Research 46:296-303.
Khanh, T.D., N.H. Hong, T.D. Xuan, and M.I. Chung. 2005. Paddy weed control by medicinal and leguminous plants from Southeast Asia. Crop Protection 24:421-431.

Kobayashi, K. 2004. Factors affecting phytotoxic activity of allelochemicals in soil. Weed Biology and Management 4:1-7.

Kobayashi, A., and H. Kato-Noguchi. 2015. The seasonal variations of allelopathic activity and allelopathic substances in Brachiaria brizantha. Botanical Studies 56:1-7.

Laosinwattana, C., T. Poonpaiboonpipat, M. Teerarak, W. Phuwiwat, T. Mongkolaussavaratana, and P. Charoenying. 2009. Allelopathic potential of Chinese rice flower (Aglaia odorata Lour.) as organic herbicide. Allelopathy Journal 24:45-54.

Machado, S. 2007. Allelopathic potential of various plant species on downy brome. Agronomy Journal 99:127-132.

Macías, F.A., J.M. Molinillo, R.M. Varela, and J.C. Galindo. 2007. Allelopathy-a natural alternative for weed control. Pest Management Science 63:327-348.

Mijangos Ricárdez, O., J. Ruiz-Jiménez, L. Lagunez-Rivera, and M. Luque de Castro. 2011. Fast ultrasound-assisted extraction of polar (phenols) and nonpolar (lipids) fractions in Heterotheca inuloides Cass. Phytochemical Analysis 22:484-491.

Nishida, N., S. Tamotsu, N. Nagata, C. Saito, and A. Sakai. 2005. Allelopathic effects of volatile monoterpenoids produced by Salvia leucophylla: Inhibition of cell proliferation and DNA synthesis in the root apical meristem of Brassica campestris seedlings. Journal of Chemical Ecology 31:1187-1203.

Omezzine, F., A. Ladhari, A. Rinez, and R. Haouala. 2011. Potent herbicidal activity of Inula crithmoides L. Scientia Horticulturae 130:853-861.

Pukclai, P., and H. Kato-Noguchi. 2010. Screening of allelopathic activity of eleven Thai medicinal plants on seedling growth of five test plant species. Asian Journal of Plant Sciences 9:486-491.

Pukclai, P., and H. Kato-Noguchi. 2012. Allelopathic potential of Tinospora tuberculata Beumee on twelve test plant species. Journal of Plant Biology Research 1:19-28.

Saito, K. 2010. Weed pressure level and the correlation between weed competitiveness and rice yield without weed competition: An analysis of empirical data. Field Crops Research 117:1-8.

Seal, A.N., J.E. Pratley, T.J. Haig, M. An, and H. Wu. 2010. Plants with phytotoxic potential: Wollemi pine (Wollemia nobilis). Agriculture, Ecosystems \& Environment 135:52-57.

Sodaeizadeh, H., M. Rafieiolhossaini, and P. Van Damme. 2010. Herbicidal activity of a medicinal plant, Peganum harmala L., and decomposition dynamics of its phytotoxins in the soil. Industrial Crops and Products 31:385-394.

Tefera, T. 2002. Allelopathic effects of Parthenium hysterophorus extracts on seed germination and seedling growth of Eragrostis tef. Journal of Agronomy and Crop Science 188:306-310.

Xuan, T.D., E. Tsuzuki, H. Terao, M. Matsuo, T.D. Khanh, and S. Muryama. 2003. Alfalfa, rice by-products and their incorporation for weed control in rice. Weed Biology and Management 3:137-144. 